\title{
Neoplastic Paneth cells ${ }^{1}$
}

\author{
KLAUS LEWIN ${ }^{2}$ \\ From the Vincent Square Laboratories of Westminster Hospital, London
}

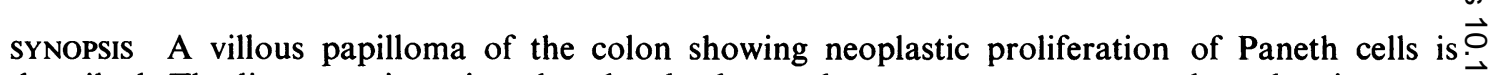
described. The literature is reviewed and only three other tumours are accepted as showing neo- $\overrightarrow{\vec{\omega}}$ plastic proliferation of Paneth cells.

Paneth cells were discovered by Schwalbe in 1872 and described more fully by Paneth in 1888 . They have been found since in the intestinal mucosa of a wide variety of animals. They are found in the fundus of the crypts of Lieberkühn and their characteristic feature is the large granules visible in both the fresh and fixed state in the apical or upper part of the cell (Fig. 1).

In man they occur naturally in the small intestine, appendix, and colon (Lewin, 1966) and have been reported in the colons of neonates (Hamperl, 1928). An increase in the number of Paneth cells has been reported in inflammatory disease of the appendix

${ }^{1}$ Based on a thesis for the M.D. degree of the University of London. ${ }^{2}$ Present address: Area Department of Pathology, Church Lane, Heavitree, Exeter, Devon.

Received for publication 7 September 1967.

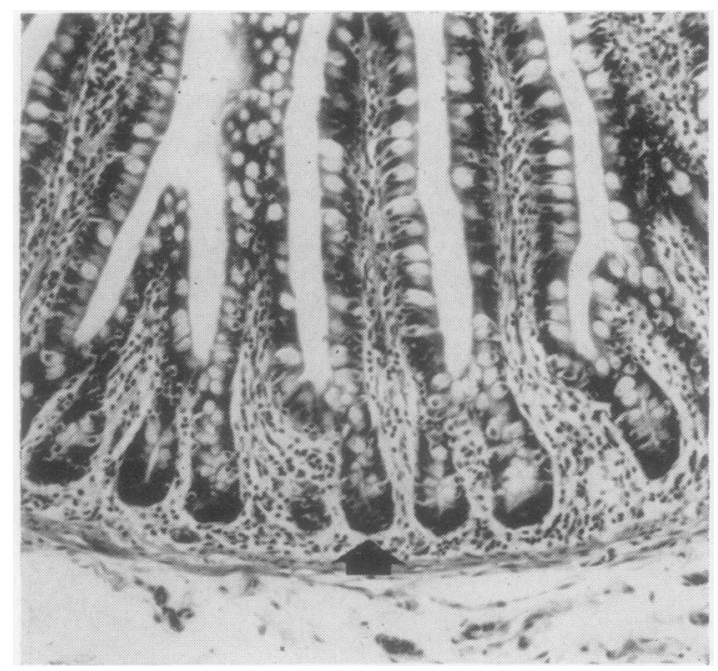

FIG. 1. Normal mucosa of human small intestine to show Paneth cells (arrowed) at fundus of crypts of Lieberkühn Haematoxylin and eosin $\times 360$.
(Kitagawa and Takahashi, 1958) and in the colon in connexion with ulcerative colitis (Watson and Roy, 1960; Paterson and Watson, 1961; and others) in oे tuberculous 'typhlits' (Hertzog, 1937), and in 음 adenoma and carcinoma (Thorel, 1898; Schmidt, 1905; Kerr and Lendrum, 1936; Morson, 1955; Lauren, 1961).

The proliferative ability of the Paneth cell is $\vec{\varphi}$ weak and it is doubtful whether the Paneth cell has ever been seen in the mitotic phase. Its ability to proliferate has been deduced by its denser occurrence in polyps than in the mucosa of the immediate vicinity. Until 1960 no convincing case of neoplastic proliferation of the Paneth cell had been reported $\frac{\mathrm{D}}{\varnothing}$ although Saltykow (1901) reported Paneth cells in a case of carcinoma of the stomach. However, intes-o을 tinal metaplasia was seen in the normal mucosa contiguous with the carcinoma and the question of retained Paneth cells in the carcinoma cannot be excluded. Hamperl (1928) described them in a case용 of 'mature intestinal cancer' but does not mention $\overline{-}$ the nature of the lesion or the situation of the cells. 3 .

Since 1960, there have been two reports of $\delta$ neoplastic proliferation of Paneth cells (Stern and $₹$ Sobel, 1961; Holmes 1965), and the object of this 0 paper is to report another example which I came $D$ across during studies of the Paneth cell in diseases of the colon.

\section{MATERIAL}

The specimen was fixed in $10 \%$ formol saline for $24 \mathrm{~N}$ hours, followed by ordinary processing (in a histo- $\sigma$ kinette machine) and paraffin wax embedding. The sections were stained with haematoxylin and eosin and $\frac{\text { CO }}{5}$

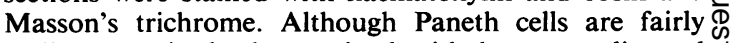
easily recognized when stained with haematoxylin and ${ }^{+}$ eosin, I found that Masson's trichrome gave the best $\underset{T}{T}$ contrast between the granules, the nucleus, and the surrounding stroma.

CASE REPORT

A 63-year-old man first presented in 1952 at the age of 


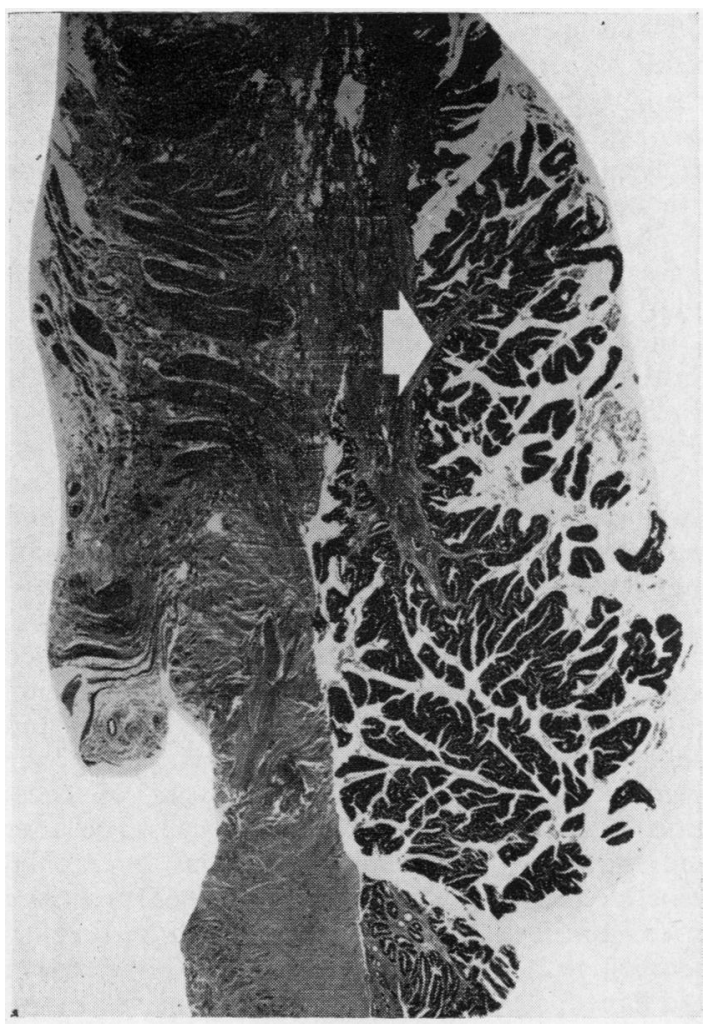

FIG. 2.

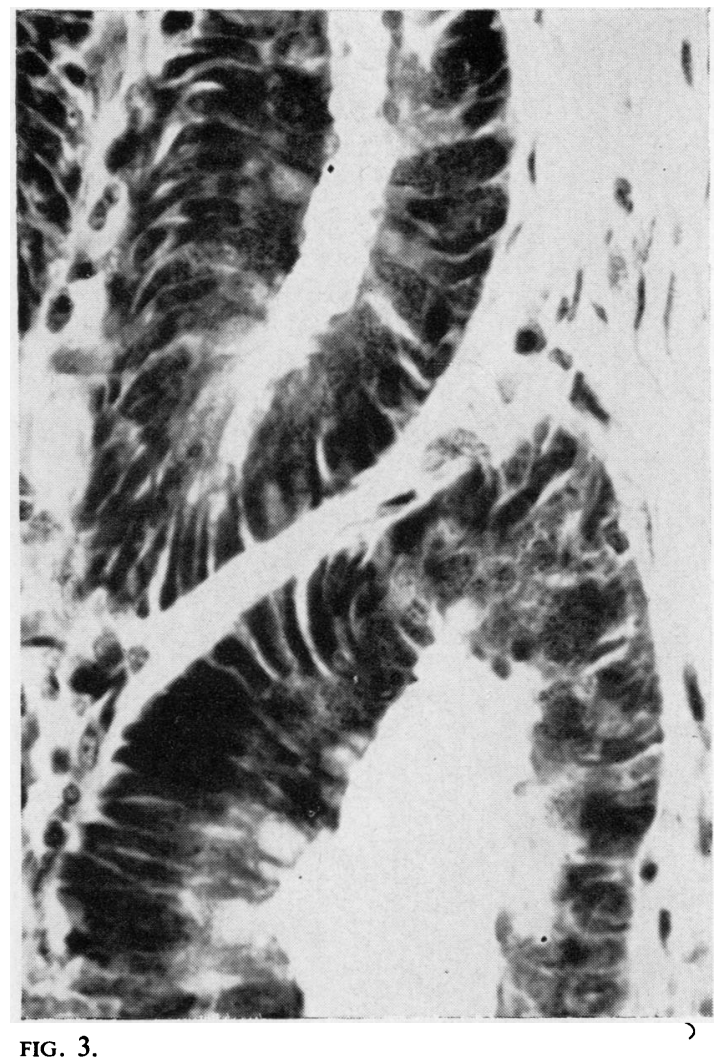

FIG. 3.
50 with a rectal papilloma which was resected with local diathermy. The papilloma recurred persistently and was resected on 13 occasions over the next 10 years. All biopsies showed benign villous papilloma and only one of them contained a few Paneth cells within the neoplastic glands. By 1962 the papilloma had become too extensive for local resection and abdomino-perineal excision was therefore decided upon. The patient made an uneventful recovery and when last seen in 1966 remained in good health.

The abdomino-perineal resection consisted of the terminal $29 \mathrm{~cm}$ of the large intestine and the anus. About $4 \mathrm{~cm}$ from the pectoneal line was a papillary tumour with an irregular outline and it extended for a distance of about $4 \mathrm{~cm}$. The growth did not appear to have breached the muscle coats, and there were no enlarged lymph nodes. Microscopic examination showed a typical villous papilloma which did not contain any inclusions of normal glandular epithelium at its base. There were numerous delicate elongated villi lined by tall columnar cells, some of which were secreting mucus. The bases of the villi consisted of large shallow crypts and these were lined predominantly by Paneth cells and a few columnar cells (Figs. 2 and 3). Paneth cells were not seen on the villi. Structurally, therefore, the architecture of the tumour resembled small intestinal mucosa, the villi and the crypts containing Paneth cells.

\section{DISCUSSION}

The presence of Paneth cells in benign colonic tumours has been established by several workers (Schmidt, 1905; Morson, 1955; Watson and Roy, 1960; Lewin, 1966). However, they are not truly neoplastic, as they do not form part of the neoplastic tissue and appear to be remnants of normal colonic epithelium which has been overgrown by the neoplastic glands (Fig. 4). The explanation for the presence of the Paneth cells is uncertain. Lauren (1961) believes that there is some factor in the mucosa around the tumour in the large intestine that causes them, and Watson and Roy (1960) state that they are caused by chronic irritation and that their function is to protect the mucosa. Black and Ogle 


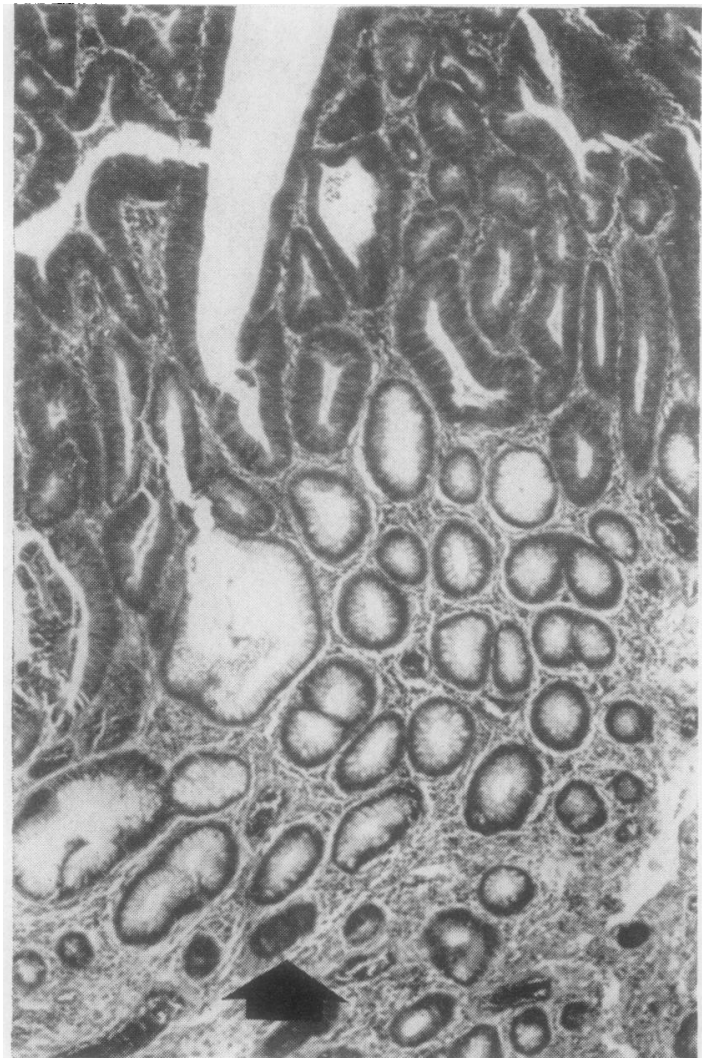

FIG. 4. Adenomatous rectal polyp containing Paneth cells at its base (arrowed). Paneth cells do not form part of the neoplastic tissue but are within remnants of normal colonic epithelium which has been overgrown by the neoplastic glands. Haematoxylin and eosin $\times 360$.
(1948) suggest that the Paneth cells appear as a result of a simple metaplastic change in the mucosao brought about by the altered milieu. I believe the last explanation is the most likely, because in aw study of the effects of disease on the large intestineo I found Paneth cells in the colon wherever there waso damage, and it seemed to me that the appearance of $\frac{5}{5}$ these cells was part of the mucosal reaction to $\mathbb{\Omega}$ injury.

क

In order to label Paneth cells neoplastic they must form an integral part of the tumour tissue. The best: explanation for their rarity was given by Lauren $\vec{\omega}$ (1961), who said that it indicated nothing more thano the formation of carcinoma in a part of the mucosas with no Paneth cells, ie, the surface epithelium andiv the upper parts of the crypts (Fig. 5). He prophesied $d_{\vec{A}}^{-}$ that since there were exceptions to the rule, that is, of tumours developing from the surface epithelium, $/ 2$ carcinoma containing Paneth cells could be expectedo from growths originating in the deeper epithelium.His prognostication has been realized. Stern and $c$ Sobel (1961) described a case of carcinoma of the jejunum which contained three types of cells: $\overrightarrow{0}$ mucous, undifferentiated, and Paneth cells. The lattero had the same histochemical reactions as normal Paneth cells. More recently Holmes (1965) described three more cases. However, she does not distinguish $\stackrel{5}{\square}$ between truly neoplastic Paneth cell proliferation? and Paneth cell inclusions within a neoplastic lesion. $\frac{\mathrm{D}}{\mathrm{Q}}$ One of her examples, an adenoma, merely contains a few non-neoplastic Paneth cells within its substance. $\overrightarrow{\overrightarrow{0}}$ The other two, a carcinoma of the jejunum and an adenoma of the colon, do fulfil the criteria for neoplastic proliferation.

Paneth cells have also been produced in experi

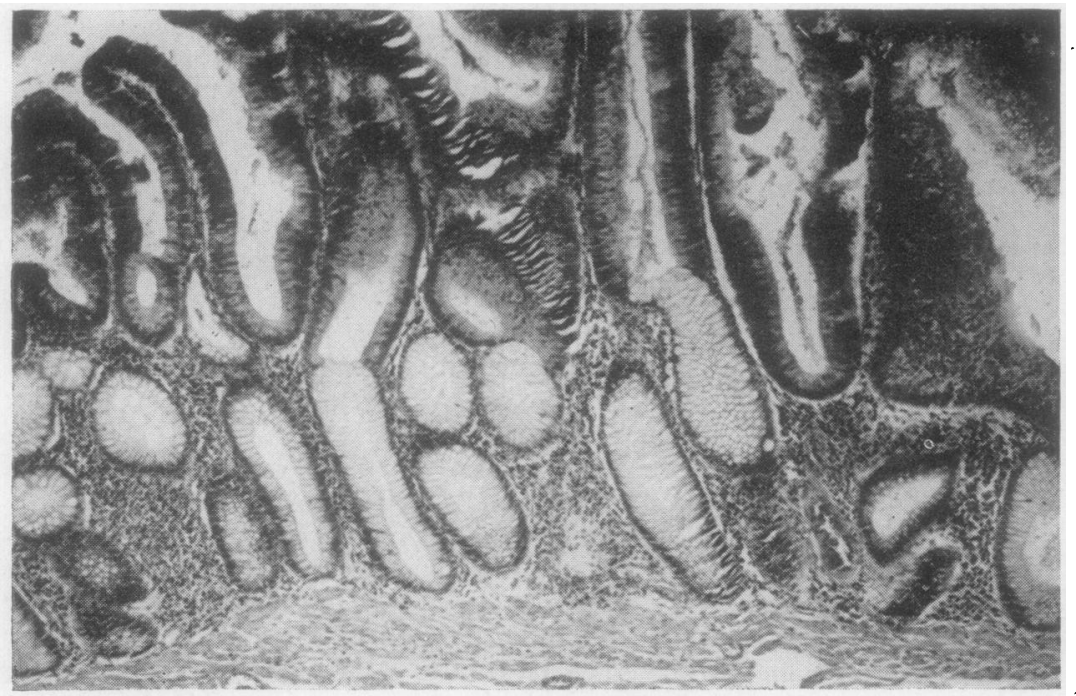

FIG. 5. Adenomatous rectal polyp to show development of neoplastic tissue from superficial portion of mucosa. Haematoxylin and eosin $\times 360$. 
mentally induced small intestinal carcinoma (Dunn and Kessel, 1945; Stewart and Lorenz, 1947). Rats fed on methylcholanthrene, a carcinogenic hydrocarbon, developed tumours of the small intestine containing Paneth cells in the basal portions of the neoplastic glands. These tumours appeared diferent, however, from lesions in the human gut in that they resembled 'whole organ malignancies', $i e$, the whole organ appeared to have become neoplastic, as opposed to a neoplasm of unicellular or focal origin.

It is difficult to discuss the prognosis of patients with neoplastic lesions containing Paneth cells because so few have been described and their postoperative courses have not been mentioned. I believe that in the case of adenoma the outlook is not significantly affected. In the case of carcinoma, it would seem reasonable to suppose that the presence of Paneth cells represents a high degree of differentiation of the tumour cells and therefore the prognosis would be that of a well differentiated adenocarcinoma.

I am indebted to Dr Ian Dawson for his constant help and encouragement, to $\mathrm{Mr} \mathrm{R}$. Morton for assistance with the photomicrographs, and Mrs H. Francis for technical assistance. I should also like to thank $\mathrm{Mr} \mathrm{S}$. O. Aylett for permission to study the case record of this patient under his care.

\section{REFERENCES}

Black, C. E., and Ogle, R. S. (1948). Arch. Path., 46, 107.

Dunn, T. B., and Kessel, A. M. (1945). J. nat. Cancer Inst., 6, 113. Hamperl, H. (1928). Beitr. path. Anat., 80, 307.

Hertzog, A. J. (1937). Amer. J. Path., 13, 351.

Holmes, E. J. (1965). Cancer (Philad.), 18, 1416.

Kerr, A. B., and Lendrum, A. C. (1936). Brit. J. Surg., 23, 615. Kitagawa, T., and Takahashi, T. (1958) Arch. histol. jap., 14, 329. Cited by Lauren, P. (1961).

Lauren, P. (1961). Acta path. microbiol. scand., suppl. 152.

Lewin, K. (1966). M.D. Thesis, University of London.

Morson, B. C. (1955). Brit. J. Cancer, 9, 550.

Paneth, J. (1888). Arch. Mikr. Anat., 31, 113.

Paterson, J. C., and Watson, S. H. (1961). Amer. J. Path., 38, 243.

Saltykow, A. (1901). Beitrag zur Kenntnis der hyalinen Körper und der eosinophilen Zellen in der magenschleimhaut und in anderen Geweben. Buchdruckerei des Schweiz Grütlevereins, Zurich. Cited by Lauren, P. (1961).

Schmidt, J. E. (1905). Arch. mikr. Anat., 66, 12.

Schwalbe, G. (1872). Ibid., 8, 92.

Stern, J. B., and Sobel, H. J. (1961). Arch. Path., 72, 47.

Stewart, H. L., and Lorenz, E. (1947). J. nat. Cancer Inst., 7, 239.

Thorel, C. (1898). Virchows Arch. path. Anat., 151, 319.

Watson, A. J., and Roy, A. D. (1960). J. Path. Bact., 80, 309. 